\title{
Reading the Beatitudes (Mt 5:1-10) through the lenses of introverted intuition and introverted sensing: Perceiving text differently
}

\begin{tabular}{|c|c|}
\hline \multicolumn{2}{|c|}{$\begin{array}{l}\text { Authors: } \\
\text { Leslie J. Francis }{ }^{1,4} \text { (D) } \\
\text { Duncan Strathie }{ }^{2,4} \\
\text { Christopher F. Ross }\end{array}$} \\
\hline $\begin{array}{l}\text { Affiliations: } \\
{ }^{1} \text { Warwick Reli } \\
\text { Education Res } \\
\text { University of } \\
\text { Coventry, Uni }\end{array}$ & $\begin{array}{l}\text { Jions and } \\
\text { earch Unit, } \\
\text { Narwick, } \\
\text { ed Kingdom }\end{array}$ \\
\hline $\begin{array}{l}{ }^{2} \text { Diocese of } \mathrm{Bi} \\
\text { Birmingham, } \\
\text { Kingdom }\end{array}$ & $\begin{array}{l}\text { Emingham, } \\
\text { England, United }\end{array}$ \\
\hline $\begin{array}{l}{ }^{3} \text { Martin Luthe } \\
\text { College, Wate } \\
\text { Canada }\end{array}$ & $\begin{array}{l}\text { University } \\
\text { roo, Ontario, }\end{array}$ \\
\hline $\begin{array}{l}{ }^{4} \text { Department } \\
\text { Testament St } \\
\text { Related Litera } \\
\text { of Theology a } \\
\text { University of } \\
\text { Pretoria, Sout }\end{array}$ & $\begin{array}{l}\text { dies and } \\
\text { dure, Faculty } \\
\text { d Religion, } \\
\text { retoria, } \\
\text { Africa }\end{array}$ \\
\hline $\begin{array}{l}\text { Research Proj } \\
\text { Project Leade } \\
\text { Aarde (1) } \\
\text { Project Numb }\end{array}$ & $\begin{array}{l}\text { ect Registration: } \\
\text { r: A.G. van } \\
\text { er: } 2334682\end{array}$ \\
\hline $\begin{array}{l}\text { Description: } \\
\text { This research } \\
\text { research proje } \\
\text { Theology and } \\
\text { directed by Pr } \\
\text { van Aarde, Po } \\
\text { Professor and } \\
\text { Research Fellc } \\
\text { Office, Faculty } \\
\text { and Religion, } \\
\text { Pretoria. }\end{array}$ & $\begin{array}{l}\text { s part of the } \\
\text { ct, 'Biblical } \\
\text { Hermeneutics', } \\
\text { of. Dr Andries } \\
\text { st Retirement } \\
\text { Senior } \\
\text { w in the Dean's } \\
\text { of Theology } \\
\text { Jniversity of }\end{array}$ \\
\hline $\begin{array}{l}\text { Correspondin } \\
\text { Leslie Francis, } \\
\text { leslie.francis@ }\end{array}$ & $\begin{array}{l}\text { g author: } \\
\text { warwick.ac.uk }\end{array}$ \\
\hline $\begin{array}{l}\text { Dates: } \\
\text { Received: } 25 \mathrm{n} \\
\text { Accepted: } 04 \\
\text { Published: } 06\end{array}$ & $\begin{array}{l}\text { Mar. } 2019 \\
\text { uly } 2019 \\
\text { Dec. } 2019\end{array}$ \\
\hline Read online: & \\
\hline 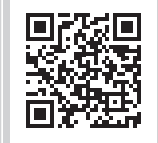 & $\begin{array}{l}\text { Scan this QR } \\
\text { code with your } \\
\text { smart phone or } \\
\text { mobile device } \\
\text { to read online. }\end{array}$ \\
\hline
\end{tabular}

Working within the reader perspective approach to biblical hermeneutics, a recent series of empirical studies has tested the theory that the readers' psychological type preferences between sensing and intuition (perceiving functions) and between feeling and thinking (judging functions) shape distinctive readings of biblical texts. This study advances the debate by distinguishing between the two orientations within which the functions are expressed (introverted and extraverted). The added clarity offered by this refinement is illustrated by the distinctive voices of introverted intuition and introverted sensing engaging with the Matthean Beatitudes, eight verses rich in materials to engage the perceiving functions.

Keywords: reader perspective; psychological type; SIFT method; psychology and Bible.

\section{Introduction}

The sensing, intuition, feeling and thinking (SIFT) approach to biblical hermeneutics and liturgical preaching is related both to wider reader response theory (Bleich 1978; Booth 1984; Fish 1980) and to the wider reader-perspective approach to the reading and interpretation of scripture (see Village 2007). While the reader-perspective approach to the interpretation of scripture was originally shaped by sociological theories giving attention to the social location of the reader in terms of factors such as gender and ethnicity (Segovia \& Tolbert 1995a, 1995b), the notion that the reader perspective might also be shaped by psychological theories was advanced by Stiefel (1992) and Bassett, Matthewson and Gailitis (1993), drawing on psychological type theory as proposed by Jung (1971). In an independent initiative, which also drew on psychological type theory, a series of theoretically driven studies by Francis (1997), Francis and Atkins (2000, 2001, 2002) and Francis and Village (2008) proposed the SIFT approach.

\section{Exploring the SIFT approach}

The SIFT approach has also been explored in a sequence of qualitative studies in which 'readers' have been invited to work in groups that share the same psychological type preferences to explore specific passages of scripture. The theory is that such groups (constituted on the basis of psychological type preference) lead to greater clarity and greater distinctiveness of the typeassociated readings of text. The following passages from the gospels have been explored in this way: the feeding of the 5000 reported in Mark 6:34-44 (Francis 2010); the resurrection narratives reported in Mark 16:1-8 and Matthew 28:1-15 (Francis \& Jones 2011); the cleansing of the Temple and the incident of the fig tree reported in Mark 11:11-21 (Francis 2012a; Francis \& ap Siôn 2016b); the Johannine feeding narratives reported in John 6:4-22 (Francis 2012b) and John 6:5-15 (Francis \& Jones 2014); the narrative of separating sheep from goats reported in Matthew 25:31-46 (Francis \& Smith 2012); the birth narratives reported in Matthew 2:13-20 and Luke 2:8-16 (Francis \& Smith 2013); two narratives concerning John the Baptist reported in Mark 1:2-8 and Luke 3:2b-20 (Francis 2013; Francis \& Smith 2014); two passages exploring different aspects of discipleship reported in Mark 6:7-14 and 6:33-41 (Francis \& Jones 2015a); the foot washing account reported in John 13:2b-15 (Francis 2015); two healing narratives reported in Mark 2:1-12 and 10:46-52 (Francis \& Jones 2015b); the narrative of blind Bartimaeus reported in Mark 10:46-52 (Smith \& Francis 2016); the Road to Emmaus narrative reported in Luke 24:13-35 (Francis \& ap Siôn 2016a; Francis \& Smith 2017); the Lucan call of the first disciples reported in Luke 5:1-7

How to cite this article: Francis, L.J., Strathie, D. \& Ross, C.F., 2019, 'Reading the Beatitudes (Mt 5:1-10) through the lenses of introverted intuition and introverted sensing: Perceiving text differently', HTS Teologiese Studies/Theological Studies 75(4), a5475. https://doi.org/10.4102/hts.v75i4.5475

Copyright: ( 2019. The Authors. Licensee: AOSIS. This work is licensed under the Creative Commons Attribution License.

Note: HTS 75th Anniversary Maake Masango Dedication. 
(Francis \& ap Siôn 2017); the missionary journey reported in Mark 6:6b-16 (Francis, Smith \& Francis-Dehqani 2017); and the Matthean pericopes on Pilate and Judas in Matthew 27:3-10, 19-25 (Francis \& Ross 2018). More recently this research tradition has also been applied to the Psalms: Psalm 1 (Francis, McKenna \& Sahin 2018; Francis \& Smith 2018) and Psalm 139 (Francis, Smith \& Corio 2018).

The SIFT approach draws on Jungian psychological type theory as made accessible through a series of psychometric instruments that operationalise the theory for empirical studies, including the Keirsey Temperament Sorter (Keirsey \& Bates 1978), the Myers-Briggs Type Indicator (Myers \& McCaulley 1985) and the Francis Psychological Type Scales (Francis 2005). This model distinguishes between two core psychological processes: the perceiving process that is concerned with gathering information and the judging process that is concerned with evaluating information. Jung helpfully described perceiving as the irrational process as it was not concerned with evaluation and judging as the rational process as it was concerned with evaluation. The theory suggests that each process is reflected in two contrasting functions.

The two perceiving functions are styled sensing and intuition. The two judging functions are styled feeling and thinking. The Jungian theory suggests that optimal human functioning draws on all four psychological functions: sensing (S), intuition (I), feeling (F) and thinking (T). The SIFT approach to biblical hermeneutics argues that rich engagement with the Word of God is enhanced by the engagement of all four psychological functions.

\section{Developing the SIFT approach}

Psychological type theory is both richer and more complex than simply distinguish among the four functions of sensing, intuition, feeling, and thinking. Jung's theory of psychological type not only distinguishes among the four functions but also distinguishes between the two orientations, within which each function can be expressed. On this account, the perceiving process distinguishes among four functions: extraverted sensing, introverted sensing, extraverted intuition and introverted intuition. The judging process also distinguishes among four functions: extraverted feeling, introverted feeling, extraverted thinking and introverted thinking. This approach to the psychological type theory that differentiates among the eight function orientations (rather than simply among the four functions) is rooted in the work of John Beebe $(2004,2006,2016)$ and has been explicated by Berens and Nardi (2004) and by Hartzler, McAlpin and Haas (2005).

In their general introduction to the engagement of the sensing function within the SIFT approach, Francis and Ross (2018) argue that sensing types focus on the given evidence of the present situation as perceived by the senses. Sensing types tend to be concerned with specific details, rather than the overall picture. They are concerned with the actual, the real and the practical, tending to be down to earth and matter of fact. In differentiating between extraverted sensing and introverted sensing, Hartzler et al. (2005:2) argue that for extraverted sensing types 'the focus is on information being acquired in the moment'; extraverted sensing has an outward orientation. For introverted sensing types where introverted sensing has an inward orientation, 'the focus is on information recalled from previous experience'.

In their general introduction to the engagement of the intuitive function within the SIFT approach, Francis and Ross (2018) argue that intuitive types focus on the possibilities of the situation, perceiving meanings and relationships. They tend to concentrate on associations, intuitions and the wider themes that go beyond the sense perceptions. Intuitive types tend to focus on the bigger picture and on the future possibilities, rather than on specific facts and details. In differentiating between extraverted intuition and introverted intuition, Hartzler et al. (2005:3) argue that for extraverted intuitive types the focus is on recognising patterns and identifying possibilities for new patterns and methods of associating the information' in the external world. Extraverted intuition has an outward orientation. For introverted intuitive types, 'the focus is on synthesising information, identifying the deeper and ultimate meaning as symbolism represented by the information'. Introverted intuition has an inward orientation.

In their general introduction to the engagement of the feeling function within the SIFT approach, Francis and Ross (2018) argue that feeling types form evaluations based on subjective personal and interpersonal values. They emphasise compassion and mercy. They are known for their tactfulness and desire for peace. They are more concerned with providing harmony than adhering to abstract principles. In differentiating between extraverted feeling and introverted feeling, Hartzler et al. (2005:3) argue that for extraverted feeling types, the focus is on attempts 'to arrive at a decision that maintains harmony in the group'. Extraverted feeling has an outward orientation aware of external comfort and discomfort and is concerned with maximising harmony among people. For introverted feeling types, the focus is on attempts 'to accept only decisions that are consistent with core values'. Introverted feeling has an inward orientation aware of internal comfort and discomfort and is concerned with maximising harmony and congruence inside the individual.

In their general introduction to the engagement of the thinking function within the SIFT approach, Francis and Ross (2018) argue that thinking types form evaluations based on objectives and impersonal logic; they emphasise integrity and justice. They are known for their truthfulness and desire for fairness. They consider conforming to principles to be more important than cultivating harmony. In differentiating between extraverted thinking and introverted thinking, Hartzler et al. (2005:3) argue that for 
extraverted thinking types, the focus is on 'applying objective analysis to information or data' in order 'to arrive at a logical, defendable decision'; extraverted thinking has an outward orientation concerned with order in the public arena. For introverted thinking types, the focus is on 'applying system analysis to information or data' to 'ensure consistency and precision'; introverted thinking has an inward orientation concerned with an ordered inner structure.

\section{Research question}

The aim of this study was to invite individuals who were well versed in the psychological type theory (and attending a residential seminar arranged by the Network for Psychological Type and Christian Faith) to function as a hermeneutical community working in small groups on the basis of their dominant function orientation. The passage of scripture on which the individuals were invited to focus was the Matthean Beatitudes. It was hypothesised that these eight Beatitudes are rich in material engaging the perceiving process and that clear contrasts would emerge between the ways in which introverted intuition and introverted sensing deal with the material. Studies on the type profile of religious communities indicate that introverted sensing and introverted intuition tend to be more prevalent than extraverted sensing and extraverted intuition (see Ross 2011).

\section{Method}

\section{Procedure}

In the context of a residential meeting convened in England by the Network for Psychological Type and Christian Faith, participants were given the opportunity to take part in a workshop designed to provide an experience of exploring scripture in groups organised on the basis of their dominant function orientation.

Before dividing the participants into groups, Matthew 5:1-10 from The Jerusalem Bible translation was read aloud. Printed copies of the passage were provided to each participant, with the instruction 'draw on your dominant type to discuss the passage'. In accordance with their own type preferences, the two lead authors convened the groups identifying introverted intuition and introverted sensing both to participate in and engage with the discussion. They also recorded the conversations.

\section{Participants}

The workshop was attended by 22 participants ( 9 men and 13 women). Within this group, preference for intuition was more prevalent than preference for sensing (17 compared with 5), and preference for feeling was more prevalent than preference for thinking (12 compared with 10). While six participants identified with introverted intuition, only two participants identified with introverted sensing.

\section{Results Introverted sensing}

Hartzler et al. (2005:9) speak about introverted sensing as recalling previous experience in detail, as shaping perceptions of the present through association with the past and as assembling new information in a slow and methodical manner, cross-checking carefully with previous experience and inner images. Displaying these qualities, the group of introverted sensing types found it difficult to commence the task because they felt they had been given insufficiently precise information concerning what was expected from them. Simply being asked to 'draw on your dominant type to discuss the passage' was not a sufficiently well-defined task to get them started. They found that being asked to discuss the passage without defining how, why or with what focus was problematic. They asked, 'what is the intended outcome?'. Without having an answer to that question they argued that they would need to make a number of assumptions that might lead to an analysis that failed to provide what was in fact wanted.

Looking for a starting point that might link with and draw on his previous experience, one member of the group recalled that the recurrent reference of the Beatitudes was rooted in the Greek word makarios.

Now that word makarios held for him a very powerful emotive experience from the childhood. He had been born into a military family, and when he was 6 months old, his father's regiment was diverted to Cyprus to defend British interests against the Cypriot Independence Movement which was led by Archbishop Makarios. For him, far from being a word that engenders happiness, each time he hears or recalls the word, makarios means danger as the EOKA-B terrorists targeted British military personnel and their families. He had lived in Cyprus for 4 years, and the deep-rooted images were engrained.

Having given time to listening to this recollection from the past, members of the group began to identify the information that they needed to get on with the task in hand. Four core questions were identified:

- Is the focus of the Beatitudes eschatological, is it allegorical, is it metaphorical or is it literal? What had Jesus or the writer in mind?

- Does the form of the Beatitudes follow a recognised pattern from ancient wisdom literature or something similar?

- What is the nature of the transaction that takes place in each of the clauses of the Beatitudes?

- In which currency is the transaction made?

To begin to address these questions, the group wanted to be clear about the group to whom Jesus was speaking the Beatitudes. The translation at hand seemed to make it clear that Jesus was speaking directly to the disciples. The next step in the close examination of the Beatitudes involved 
looking clearly at the eight clauses and attending to details of interest and of potential significance.

They noted the use of the verb 'are' in clauses 1 and 3 (Happy are those who mourn). They wanted to know in what sense that made those two clauses different. They singled out the opening word 'how' in the first clause. They wanted to know what extra weight that gave to the clause. They pointed out that both the first and the last Beatitudes referred to the kingdom of heaven. They saw these 'bookending' the other six Beatitudes and suggested that everything in these other six clauses may give glimpses of what it means to dwell fully within the kingdom.

Re-reading the eight Beatitudes for a further time, they began to note how this translation resonated with translations with which they were familiar from an early time. In the first Beatitude, the word 'lowly' popped to mind rather than 'poor'. In the second Beatitude, the word 'meek' popped to mind rather than 'gentle'.

Some words or images prompted full reflection. In the fourth Beatitude, the language of 'hunger and thirst' revealed a real appetite and stimulated a deep reaction. In the seventh Beatitude, the choice of the gender-specific word 'sons' was felt to be so much more powerful than the gender neutral term 'children'.

In the culture in which the Beatitudes were rooted, 'sons' connoted a full inheritance. To change this to children or to another inclusive term dilutes the strength of the inheritance. This Beatitude is to do with son-ship in a paternal culture where men alone inherit.

On a further reading of the eight Beatitudes, the introverted sensing types group attempted to summarise their understanding of each of the clauses:

- The first clause is saying the last shall be first. But does the kingdom of heaven only belong to the poor in spirit? What about the others?

- The second clause is saying that the meek shall have the earth for their inheritance. But what does that mean?

- The third clause is saying that those who mourn shall be comforted. At some point everyone mourns, so this is a universal statement, unless it is applied to some group mourning over something specific.

- The fourth clause is saying that those who seek after what is right shall be satisfied. So justice will prevail.

- The fifth clause is saying that the merciful shall receive mercy. So this is a form of the Golden Rule, to do as you would be done by.

- The sixth clause is saying that the pure of heart shall see God. So here the goal of seeing God is realised.

- The seventh clause is saying that the peacemakers shall be called sons of God. So here peace is the normal state.

- The eighth clause is saying that those who are persecuted in the cause of right gain the kingdom of heaven. So is this an encouragement to fight?
Having looked at the text with this level of detail, the group were still left wondering what they had achieved. They were left asking, 'so what? what is the practical application of all of this?'. That realisation, however, triggered another clearly recalled experience for a member of the group.

I was reminded of preaching at St Barnabas Darby Green on the morning Princess Diana died. At the back of the church facing the pulpit were a series of banners depicting the Beatitudes. I wondered if this was a message to ensure the preacher remained humble!

With that deeply felt reminiscence of a previous occasion on which the Beatitudes left a lasting impression on that participant who had dominant introverted sensing, the session came to an abrupt halt. The bell was rung for dinner, and a different priority came to the forefront of the group.

\section{Introverted intuition}

Hartzler et al. (2005:11) speak about introverted intuition as 'reading between the lines', as searching for deeper meaning and as being excited by the unknown. Displaying these qualities, the group of introverted intuitive types seemed to relish exploring the intricacies - or perhaps more aptly for introverted intuitive types, the complexities - of this classic example of Matthew's complicated style of writing. After a period of silent individual contemplation, members of the group began to share their insights and their questions as they sought to uncover meaning, patterns and possibilities.

The less familiar translation of The Jerusalem Bible to these intuitive readers enabled them to access the familiar patterned text in a new light. The Matthean structure of beginning and closing the Beatitudes with the same refrain 'theirs is the kingdom of heaven' stood out. Here is proclamation about the present reality leading into the future possibilities. The repetition of the common refrain for the other six Beatitudes at first seemed to be voiced in a different tense: they shall have, they shall be, they shall see. Yet here too the introverted dominant intuitive group saw the combined promise of future and of present. These were not rewards for which they were waiting. They are rewards made present now.

The translation in The Jerusalem Bible of the opening word of each clause that is so memorably repeated, makarios in the Greek, was of great concern among the introverted intuitive types group. The unfamiliar translation of makarios as happy caused considerable excitement and disagreement. The group explored a number of meanings for the word 'happy' before dismissing the concept as insubstantial and lightweight.

Blessed is a much richer and more inviting concept that describes a deep state of being and as an outworking of the right relationship with God. Going straight for the big picture one member of the group suggested that Jesus is the Beatitudes: Jesus embodies all eight qualities. Such a bold Christological assertion posed further rather poignant 
questions regarding Christian discipleship and Christian spirituality.

Are we as Jesus' followers expected to reflect all these qualities as individuals? Or are we expected to nurture one of them and to make that our special gift to the Jesus community? This member's reflection led to considering the status of the eight qualities identified in the Beatitudes. Are these the qualities of the Godhead, or of the Christian community? And why these eight: are they a definitive list?

Trying to think afresh about the Beatitudes and grasping a new vision of their meaning required for some an active distancing of themselves from a lifetime of listening to others preach about the passage, and from memories of the Life of Brian confusing the peacemakers with the cheesemakers. There were just so many directions in which speculation could go. The Beatitudes flourish at weddings, at funerals, at the feast of All Saints. Introverted intuitive types struggled with any attempt to limit, constrain or contextualise the Beatitudes. Any single interpretation was just not good enough.

The Beatitudes are so rich in concepts that spark the imagination. For a while, the group explored the rich imagery of the merciful. Operating in a type-aware environment, it appeared natural for the group of introverted intuitive types to wonder whether different types might display and express mercy in different ways. We can all be merciful, but thinking types and feeling types may show this in quite different ways. Grasping for a sense of completeness, one member of the group speculated that if we had all types together, we would display mercy in its fullness.

Even as these thoughts and ideas continued to generate energy, that tension between the translations of makarios as happiness and blessedness could not be laid to rest. That same tension came back into play when the focus passed from the merciful to those who mourn. The argument went like this: I am mourning and therefore I am not happy but that does not prevent me from feeling blessed. Keen to explore further possibilities to complete the picture, the group lapsed into searching other translations available online. The New Living Translation says, 'God blesses those who ...'. The Message says, 'You are blessed when'; the King James Bible says, 'Blessed are those ...'. This search resulted in a cascade of reflections on the power of the root meaning as blessing. The idea of blessing connects immediately even if its meaning is not clear; saying the word 'blessing' to someone warms the heart. It comes as a comfort. People really want to be blessed. Blessing and blessedness are really rich - it is something that is bestowed on you from outside. It is impossible to feel happy when you are mourning, but God can still pour blessing on you. Introverted intuition had by now woven a rich tapestry of ideas that seemed themselves to be a blessing to the group.

Attention then returned to the poetic structure of the Beatitudes and to the powerful use of repetition. So the attention turned to the kind of speakers who draw on and who employ the power of repetition. On this account, Jesus was positioned as a left-wing, counter-cultural revolutionary whose oratory was both inspiring and exciting for the crowd, 'I see this as a socialist church', interjected one of the group. Jesus was empowering the crowd to stand up for the kingdom. Such a stand may bring pain and suffering in the first instance, but in the long term it will bring the reward of blessing.

Before the group's conversation could spark off in yet another direction, the bell was rung for dinner, but this did not prevent members of the group from continuing energised discussion as they made their way to the dining room.

\section{Discussion \\ Recognising introverted sensing}

Introverted sensing recognises details. Literally, introverted sensing orients to the present by looking out for what is familiar and selecting that part of the present because it has been strongly experienced before and is therefore safe and comfortable. Through this process of elision, the past is 'recognised' by introverted sensing in the sense of 'being known again'. At the outset of the discussion, comment was made regarding how words used in The Jerusalem Bible translation reminded them of more familiar translations, 'lowly' instead of 'poor' and 'meek' rather than 'gentle'. Eidetic memory, in full kinaesthetic, auditory, visual and even gustatory force, is delivered to consciousness through introverted sensing. For this to occur, great focus is required.

We saw this process play out through the distinctive features that characterised the discussion of the Beatitudes in the hermeneutic community constituted in introverted sensing on account of its members sharing that function-orientation as their dominant one over the other seven in their psychological cognitive repertoire. These features include sequencing and attention to detail.

The power of aspects of present experiences to trigger eidetic visceral memories was exemplified in the strong negative association that the Greek word for blessed (makarios) had for one of the introverted sensing participants because Bishop Makarios was the name of the political leader of the movement for the independence of the Mediterranean island of Cyprus from Britain, where that participant had spent an important part of his childhood. Once this memory was expressed and heard, each clause of the Beatitudes was then focused on in turn and numbered off from one to eight. When consciousness is narrowed in this way, a deep and powerful concentration is generated that is able to penetrate to a great depth, allowing details to stand out vividly that are missed by the other three perceiving function-orientations that operate differently, but especially contrasting to introverted intuition for the purposes of this study. With this depth and power of concentration narrowed, consciousness is intensely still for a moment, before shifting to another object. Indeed 
still focus, followed by a swift and rapid shift of attention to new and intense focus, then still again, is how introverted sensing proceeds.

With each of the first two clauses of the Beatitudes a slightly different interrogative is applied. In clause 1 , the precise juxtaposition of 'poverty' alongside 'kingship' makes for stark contrast that triggers in one introverted sensing type group member's memory another rhetorical inversion of Jesus: 'the first shall be last and the last first'. The interrogative 'what about the others' invites the participants to search for other instances in the other seven clauses. The limited time, however, for discussion did not permit the completion of this search.

In a type-mixed hermeneutic community, such is usually the case at church services or bible studies, an intuitive response would have been to make a broad generalisation rather than to announce a specific search, at which the usual introverted sensing majority (e.g. Francis, Robbins \& Craig 2011) might look askance because of the absence of present evidence.

In response to the second clause that correlates meekness and inheritance, the interrogative 'but what does this mean?' does not require that there should be an answer. An unanswered question while uncomfortable may be left unanswered, with the question merely posed. For introverted sensing types, it is better to have no answer than to have an answer that was unfounded or inaccurate, or a mere approximation that intuition might be content to supply. However, the interrogative 'but what does this mean?' leaves no doubt that, if a meaning was offered, it would be either correct or not, accurate or not, because the assumptive base of introverted sensing is that there must be a singular meaning, and it is just a matter of finding the 'correct' one. By sequence of trial matchings of phrase, meaning and evidence the hermeneutic method and journey is determined and limited.

The introverted sensing type group's response to the third clause, which assures the disciples that mourning brings comfort, is caution in the face of such a generalisation, with the mitigation suggesting that possibly Jesus or the early Christian community may have grounded the declaration by having a more specific grief, or griever, or grieving group in mind. The responses to the remaining clauses share characteristic of being succinct. The fourth clause states that the desire for what is right, the right relationship with God, will be realised. This reassured the introverted sensing types group of the moral ordering of their ultimate environment: 'justice will prevail'. The fifth clause that mercy will be received by those who show it seemed to bolster a similar confidence in a prevailing moral order, in this case as an expression of the Golden Rule that is based on the reciprocating nature of love. The next clause, that the pure of heart would see God, was met with the clear response that the goal of seeing God is realised. The following claim that peacemakers were true sons of God had a surprising clarity about it. It meant to these introverted sensing types that peace is a normal or even normative state. This reflects an often hidden and so neglected aspect of the capability of introverted sensing to register an experience in a clear, original manner. It simply strikes a certain cord that is a surprise to everyone.

An account of strong eidetic memory concluded the discussion - the sight of the banner of the Beatitudes in the church on the morning of the death of Princess Diana underlined the propensity of introverted sensing if triggered to command attention irrespective of context.

\section{Recognising introverted intuition}

While with introverted sensing there is an immediate subjective resonance to what is perceived, with introverted intuition the object of perception prompts a roaming across time and space, requiring a variable period of time for this kind of reflective process to occur. Characteristically, then, the results section reports 'after a period of silent individual contemplation, members began to share their insights'. Change is invariably welcomed by introverted intuition, including in a religious context (Ross, Weiss \& Jackson 1996), and it seemed the less familiar rendering of The Jerusalem Bible was welcomed for the freshness its phrasing brought and for the stimulus to seek contemporary meaning through its variance from previous translation. Introverted intuition and introverted sensing differ in their orientation in time. Introverted sensing selects elements of present experience that relate to past sensory experience, whereas introverted intuition moves freely across past, present and future without differentiation but is particularly excited by the future because future events have not been determined or set and so provide more scope for the further play and deployment of intuition because of the relatively unlimited possibilities of what is 'not yet'.

While extraverted intuition is more singularly concerned with the near future, introverted intuition spans even more widely in terms of chronological time from distant past and further into the future. In keeping with their contrasting orientation in and to time, the introverted intuitive types group mentioned that the second phrase of each Beatitude couplet was oriented to the future through the phrases 'they shall be' or 'they shall have'. It could be argued that introverted intuition is the function orientation that greatly facilitates the Christian virtue of hope through its opening sub specie aeternitas to the future when things may well be different if suffering is pressing the present. By way of contrast, the introverted sensing group focused on the use of 'are' in the first Beatitude and wrongly attributed the present tense also to the third one. Rooted in a present that relates to the past accounts for the sense of staid stability and settledness that prevails when introverted sensing is dominant in a situation as is often the case in organised religious settings. The shadow side of this quality is liability to a certain 
'stuckness' and lack of perspective when events do not go according to a plan. With intuition in play, however, ups and downs occur frequently, and such undulations may be characterised as natural or inevitable, depending on an individual's perspective or type preference. The Beatitudes start with the present tense, but future orientation predominates and prevails. Such overlapping of time orientations may in part explain the wide appeal of the Beatitudes in the Christian traditions of spirituality, both historically and today.

The Greek word makarios effected an energetic impact in the introverted intuitive group, but not as a trigger to a specific personal historic experience as with an individual with dominant introverted sensing.

The word functioned both as an opening perturbation and as a rhizomic form that surfaces towards the end of the half hour discussion. As with the study of the intuitive hermeneutic of Pilate (Francis \& Ross 2018), the branching alliterative workings of intuition are revealed in the present study. Intuition swiftly gathers passion, and so the ensuing judgements, whether based on feeling or thinking, are swift and intense. The adjective 'happy' as a translation of the ' $m$ ' word is dismissed as inadequate and unequal to the task of conveying the depth and significance of Jesus' spiritual instruction, in contrast to the word 'blessed' that is first extolled for its depth, and then as a platform for speculation on Christology, the Trinity and even ecclesiology.

The intensity and passion of the group of introverted intuitive types that might have been disturbing if other types had been present seemed mitigated by the ready ease with which members were able to move out of engagement into reflection on the process. Some members acknowledged the challenge of putting on one side the serious and even satirical commentaries on the brief passage. This historical awareness, combined with a sensitivity to their own disposition for scattered speculation, seemed not only to enable self-restraint in the moment but also to affirm the way of knowing afforded by their dominant introverted intuition, namely that there can be no single meaning to a text.

\section{Conclusion}

This study was designed to build on and to extend the insights afforded by the SIFT approach to biblical hermeneutics. The SIFT approach, as described by Francis and Village (2008), and as deployed in the series of empirical studies identified in the introduction of this article, identified the distinctive perspectives that characterise the readings of scripture voiced by the two perceiving functions (sensing and intuition) and the two judging functions (thinking and feeling) proposed by the Jungian psychological type theory. Drawing on the insights of Beebe (2004, 2006, 2016), Berens and Nardi (2004) and Hartzler et al. (2005), this study proposed a distinction between the two orientations (introversion and extraversion) in which these functions are expressed. In particular, this study focused on the specific characteristics of introverted sensing and introverted intuition as the more strongly represented forms of sensing and intuition present within religious communities. The voices of introverted sensing and introverted intuition were articulated through type-alike hermeneutical communities, convened among type-aware participants familiar with discussing Christian scripture, who were invited to engage with the Matthean Beatitudes (Mt 5:1-10).

The main conclusion drawn from this study is that the specific focus on the introverted form of sensing and the introverted form of intuition highlighted distinctive qualities of engagement with biblical text and enriched the depth of resonance that the SIFT method of biblical hermeneutics brings to this reader-perspective approach regarding the interpretation of scripture. The study is clearly limited by its focus on just two of the eight function orientations, on only one passage of scripture and on a single group of participants. These limitations can be addressed by further research shaped within the same tradition. Such exploration is particularly pertinent among groups of participants who are well versed in the psychological type theory and well familiar with Christian scriptures. It is not recommended that this more specialised and more subtle approach to the psychological type theory should detract from commitment to the original formulation of the SIFT approach to biblical hermeneutics grounded in the four-function approach.

\section{Acknowledgements Competing interests}

The authors have declared that no competing interests exist.

\section{Authors' contributions}

L.J.F. designed and structured the research programme and the article. D.S. and C.F.R. contributed fully to the generation and analysis of the data, as well as to the interpretation of the findings.

\section{Ethical consideration}

This article followed all ethical standards for a research without direct contact with human or animal subjects.

\section{Funding information}

This research received no specific grant from any funding agency in the public, commercial or not-for-profit sectors.

\section{Data availability statement}

Data sharing is not applicable to this article as no new data were created or analysed in this study.

\section{Disclaimer}

The views expressed in this article are the authors' own and not an official position of their institutions. 


\section{References}

Bassett, R.L., Mathewson, K. \& Gailitis, A., 1993, 'Recognising the person in biblical interpretation: An empirical study', Journal of Psychology and Christianity 12 38-46.

Beebe, J., 2004, 'Understanding consciousness through the theory of psychological types', in J. Cambray \& L. Carter (eds.), Analytical psychology: Contemporary perspectives in Jungian analysis, pp. 83-115, Brunner Routledge Press, New York.

Beebe, J., 2006, 'Psychological types', in R. Papadopoulos (ed.), The handbook of Jungian psychology, pp. 130-152, Brunner Routledge Press, New York.

Beebe, J., 2016, Energies and patterns in psychological type: The reservoir of consciousness, Routledge, New York.

Berens, L.V. \& Nardi, D., 2004, Understanding yourself and others: An introduction to the personality type code, Telos Publications, Huntington Beach, CA.

Bleich, D., 1978, Subjective criticism, The Johns Hopkins University Press, Baltimore, MD. Booth, W.C., 1984, The rhetoric of fiction, University of Chicago Press, Chicago, IL.

Fish, S., 1980, Is there a text in this class?, Harvard University Press, Cambridge, MA.

Francis, L.J., 1997, Personality type and scripture: Exploring Mark's Gospel, Mowbray London.

Francis, L.J., 2005, Faith and psychology: Personality, religion and the individual, Darton, Longman and Todd, London.

Francis, L.J., 2010, 'Five loaves and two fishes: An empirical study in psychological type and biblical hermeneutics among Anglican preachers', HTS Theological Studies 66(1), Art. \#811, 1-5. https://doi.org/10.4102/hts.v66i1.811

Francis, L.J., 2012a, 'What happened to the fig tree? An empirical study in psychological type and biblical hermeneutics', Mental Health, Religion and Culture 15, 873-891. https://doi.org/10.1080/13674676.2012.676252

Francis, L.J., 2012b, 'Interpreting and responding to the Johannine feeding narrative: An empirical study in the SIFT hermeneutical method among Anglican ministry training candidates', HTS Theological Studies 68(1), Art. \#1205, 1-9. https://doi. org/10.4102/hts.v68i1.1205

Francis, L.J., 2013, 'Ordinary readers and reader perspective on sacred texts: Drawing on empirical theology and Jungian psychology', in J. Astley \& L.J. Francis (eds.), Exploring ordinary theology: Dimensions of everyday Christian existence and the life of the Church, pp. 87-96, Ashgate, Farnham.

Francis, L.J., 2015, 'Footwashing and diaconal ordination', in J. Vincent (eds.), The farewell discourses in practice, pp. 21-28, Deo Publishing, Blandford Forum.

Francis, L.J. \& ap Siôn, T., 2016a, 'Empirical theology and biblical hermeneutics: Exploring lessons for discipleship from the Road to Emmaus (Luke 24: 13-35)' Journal of Empirical Theology 29, 24-44. https://doi.org/10.1163/15709256 12341000

Francis, L.J. \& ap Siôn, T., 2016b, 'Jesus, psychological type and conflict: A study in biblical hermeneutics applying the reader perspective and SIFT approach to Mark 11: 11-21', HTS Theological Studies 72(4), 1-9. https://doi.org/10.4102/hts. v72i 4.3573

Francis, L.J. \& ap Siôn, T., 2017, 'Reading the Lucan call of the first disciples differently: The voices of sensing and intuition', Journal of Beliefs and Values 38, 188-198. https://doi.org/10.1080/13617672.2017.1291254

Francis, L.J. \& Atkins, P., 2000, Exploring Luke's Gospel: A guide to the gospel readings in the Revised Common Lectionary, Mowbray, London.

Francis, L.J. \& Atkins, P., 2001, Exploring Matthew's Gospel: A guide to the gospel readings in the Revised Common Lectionary, Mowbray, London.

Francis, L.J. \& Atkins, P., 2002, Exploring Mark's Gospel: An aid for readers and preachers using year $B$ of the Revised Common Lectionary, Continuum, London.

Francis, L.J. \& Jones, S.H., 2011, 'Reading and proclaiming the resurrection: An empirical study in psychological type theory among ministry training and experienced preachers employing Mark 16 and Matthew 28', Journal of Empirical Theology 24, 1-18. https://doi.org/10.1163/157092511X571141

Francis, L.J. \& Jones, S.H., 2014, 'Life in the Eucharistic community: An empirical study in psychological type theory and biblical hermeneutics reading John 6: 5-15 Pastoral Psychology 63, 281-290. https://doi.org/10.1007/s11089-013-0540-x

Francis, L.J. \& Jones, S.H., 2015a, 'An empirical approach to Mark's account of discipleship: Conversation between the Word of God and the People of God', Rural Theology 13, 69-81. https://doi.org/10.1179/1470499415Z.00000000042
Francis, L.J. \& Jones, S.H., 2015b, 'Preparing for disability awareness Sunday: An educational exercise drawing on psychological perspectives for biblical hermeneutics', International Journal of Christianity and Education 19, 197-214. hermeneutics', International Journal of Christian

Francis, L.J., McKenna, U. \& Sahin, A., 2018, 'Facing the issues raised in Psalm 1 through thinking and feeling: Applying the SIFT approach to biblical hermeneutics among Muslim educators', Religions 9(323), 1-11. https://doi. org/10.3390/rel9100323

Francis, L.J., Robbins, M. \& Craig, C.L., 2011, 'The psychological type profile of Anglican churchgoers in England: Compatible or incompatible with their clergy?', International Journal of Practical Theology 15, 243-259. https://doi.org/10.1515/ IJPT.2011.036

Francis, L.J. \& Ross, C.F., 2018, 'Psychologically-informed engagement with the Matthean pericopes on Pilate and Judas through Jungian lenses: The SIFT approach', HTS Theological Studies 74(1), Art. \#5179. https://doi.org/10.4102/ hts.v74i1.5179

Francis, L.J. \& Smith, G., 2012, 'Separating sheep from goats: Using psychological type theory in a preaching workshop on Matthew 25:31-46', Journal of Adult Theological Education 9, 175-191. https://doi.org/10.1179/ate.9.2.gw21522035374468

Francis, L.J. \& Smith, G., 2013, 'Reading and proclaiming the birth narratives from Luke and Matthew: A study in empirical theology among curates and their training incumbents employing the SIFT method', HTS Theological Studies 69(1), Art. \#2001, 1-13. https://doi.org/10.4102/hts.v69i1.2001

Francis, L.J. \& Smith, G., 2014, 'Reading and proclaiming the Advent call of John the Baptist: An empirical enquiry employing the SIFT method', HTS Theological Studies 70(1), Art. \#2718, 1-9. https://doi.org/10.4102/hts.v70i1.2718

Francis, L.J. \& Smith, G., 2017, 'Learning relationships: Church of England curates and training incumbents applying the SIFT approach to the Road to Emmaus',
HTS Theological Studies 73(4), 1-11, Art. \#4546. https://doi.org/10.4102/hts. HTS Theologice
v73i4.4546

Francis, LJ. \& Smith, G, 2018, 'Difficult texts: Psalm 1', Theology 121, 197-200. https://doi.org/10.1177/0040571X17749149

Francis, L.J., Smith, G. \& Corio, A.S., 2018, 'I hate them with perfect hatred: Exploring Psalm 139 through the Jungian lenses of sensing, intuition, feeling, and thinking', HTS Theological Studies 74(1), 1-9, Art. \#5058. https://doi.org/10.4102/hts. v74i1.5058

Francis, L.J., Smith, G. \& Francis-Dehqani, G., 2017, 'The missionary journey of Mark 6 and the experience of ministry in today's world: An empirical study in biblical hermeneutics among Anglican clergy', HTS Theological Studies 73(3), 1-7, Art. \#4560. https://doi.org/10.4102/hts.v73i3.4560

Francis, L.J. \& Village, A., 2008, Preaching with all our souls, Continuum, London.

Hartzler, M.T., McAlpine, R.W. \& Haas, L., 2005, Introduction to type and the eight Jungian functions, CPP Inc, Mountain View, CA.

Jung, C.G., 1971, Psychological types: The collected works, vol. 6, Routledge, London.

Keirsey, D. \& Bates, M., 1978, Please understand me, Prometheus Nemesis, Del Mar, CA.

Myers, I.B. \& McCaulley, M.H., 1985, Manual: A guide to the development and use of the Myers-Briggs Type Indicator, Consulting Psychologists Press, Palo Alto, CA.

Ross, C.F.J., 2011, 'Jungian typology and religion: A perspective from North America', Research in the Social Scientific Study of Religion 22, 165-191. https://doi. org/10.1163/ej.9789004207271.i-360.30

Ross, C.F.J., Weiss, D. \& Jackson, L., 1996, 'The relation of Jungian psychological type to religious attitudes and practices', The International Journal for the Psychology of Religion 6, 263-279. https://doi.org/10.1207/s15327582ijpr0604_3

Segovia, F.F. \& Tolbert, M.A. (eds.), 1995a, Reading from this Place: Social location and biblical interpretation in the United States, Fortress Press, Minneapolis, MN.

Segovia, F.F. \& Tolbert, M.A. (eds.), 1995b, Readings from this Place: Social location and biblical interpretation in global perspective, Fortress Press, Minneapolis, MN.

Smith, G. \& Francis, L.J., 2016, 'Difficult texts: Mark 10: 46-52', Theology 119, 200-203. https://doi.org/10.1177/0040571X15623706

Stiefel, R.E., 1992, 'Preaching to all the people: The use of Jungian typology and the Myers-Briggs Type Indicator in the teaching of preaching and in the preparation of sermons', Anglican Theological Review 72, 175-202.

Village, A., 2007, The Bible and lay people: An empirical approach to ordinary hermeneutics, Ashgate, Aldershot. 